\title{
A kérgestest (corpus callosum) múködési zavarainak vizsgálata: Esettanulmány a diákkutatások, mint a tehetséggondozás fontos módszerének alkalmazásáról
}

\author{
Mészáros Lukács ${ }^{\mathrm{a}, \mathrm{b}}$, Trembeczki Mária ${ }^{\mathrm{a}}$, Matányi Marianna ${ }^{\mathrm{a}} \&$ Kákonyi Marcell ${ }^{\mathrm{a}}$ \\ ${ }^{a}$ Ferences Gimnázium, 2000 Szentendre, Áprily Lajos tér 2. \\ ${ }^{b}$ Eötvös Loránd Tudományegyetem, Őslénytani Tanszék, 1117 Budapest, Pázmány Péter sétány 1/C.
}

Mészáros L., Trembeczki M., Matányi M. \& Kákonyi M. (2018): A kérgestest (corpus callosum) müködési zavarainak vizsgálata: Esettanulmány a tudományos diákkutatások, mint a tehetséggondozás fontos módszerének alkalmazásáról. Investigation of corpus callosum anomalies: A case study on applying scientific research in the education for talented students. Acta Pintériana, 4, 5-20.

\begin{abstract}
In this article we present an investigation carried out during a high school project for talented students. During a two-year-long development we created an electronic device which is suitable for separate examination of the right and left cerebral hemispheres and cross-linked vision reflexes. The equipment was built with the purpose to point out people who have disturbances in the passage of the stimulus across the corpus callosum. The necessary technical equipment and the control and data analisator software were made by the research team. Testing of the device was made on average and corpus callosum problematic students. In the future the equipment can be applied as a diagnostic tool in the therapy of children with corpus callosum agenesia and dysgenesia.
\end{abstract}

Összegzés: A jelen cikkben egy középiskolai tehetséggondozó projekt során végzett kutatást mutatunk be. A két évig tartó fejlesztés eredményeképpen olyan elektronikus eszközt építettünk, amely alkalmas a jobb és a bal agyfélteke által irányított, valamint keresztezett látási reflexek elkülönített vizsgálatára. A berendezés azzal a céllal készült, hogy ki tudjuk szürni azokat a személyeket, akiknél az ingerület áthaladása a corpus callosumon valamiféle zavart szenved. Az ehhez szükséges technikai berendezést, valamint a vezérlő és adatfeldolgozó software-t a kutatócsoport alkotta meg. A kész eszköz tesztelését átlagos, valamint kérgestesti problémával küzdő személyeken végeztük. A diagnosztikai célra is használható berendezés a jövőben alkalmas lehet corpus callosum agenesiában és corpus callosum dysgenesiában szenvedő gyermekek korai diagnosztizálására.

\section{Bevezetés és pedagógiai vonatkozások}

A szentendrei Ferences Gimnázium tehetséggondozó programjának fontos eleme az olyan diákkutatások szervezése, amelyek a mentortanárok (zömében a Ferences Kutató tanárok Tudományos Körének ${ }^{1}$ tajgai) egyetemeken vagy más kutatóhelyeken végzett tudományos tevékenységébe való bekapcsolódás révén bevezeti a tanulókat a tudomány módszertanába, úgy, hogy eközben tevékenyen hozzájárulhatnak az eredmények megszületéséhez (MÉSZÁros 2015a). A természettudományos diákkutatásokat elsősorban a Pintér Ernő Tudományos Diákkör fogja össze, amely a Ferences Gimnázium hajdani, nemzetközi hírü biológus tanáráról kapta a nevét (SUBAI \& FEHÉR 2002).

\footnotetext{
${ }^{1}$ http://acta-pinteriana.hu/a0/fkttk.html
} 


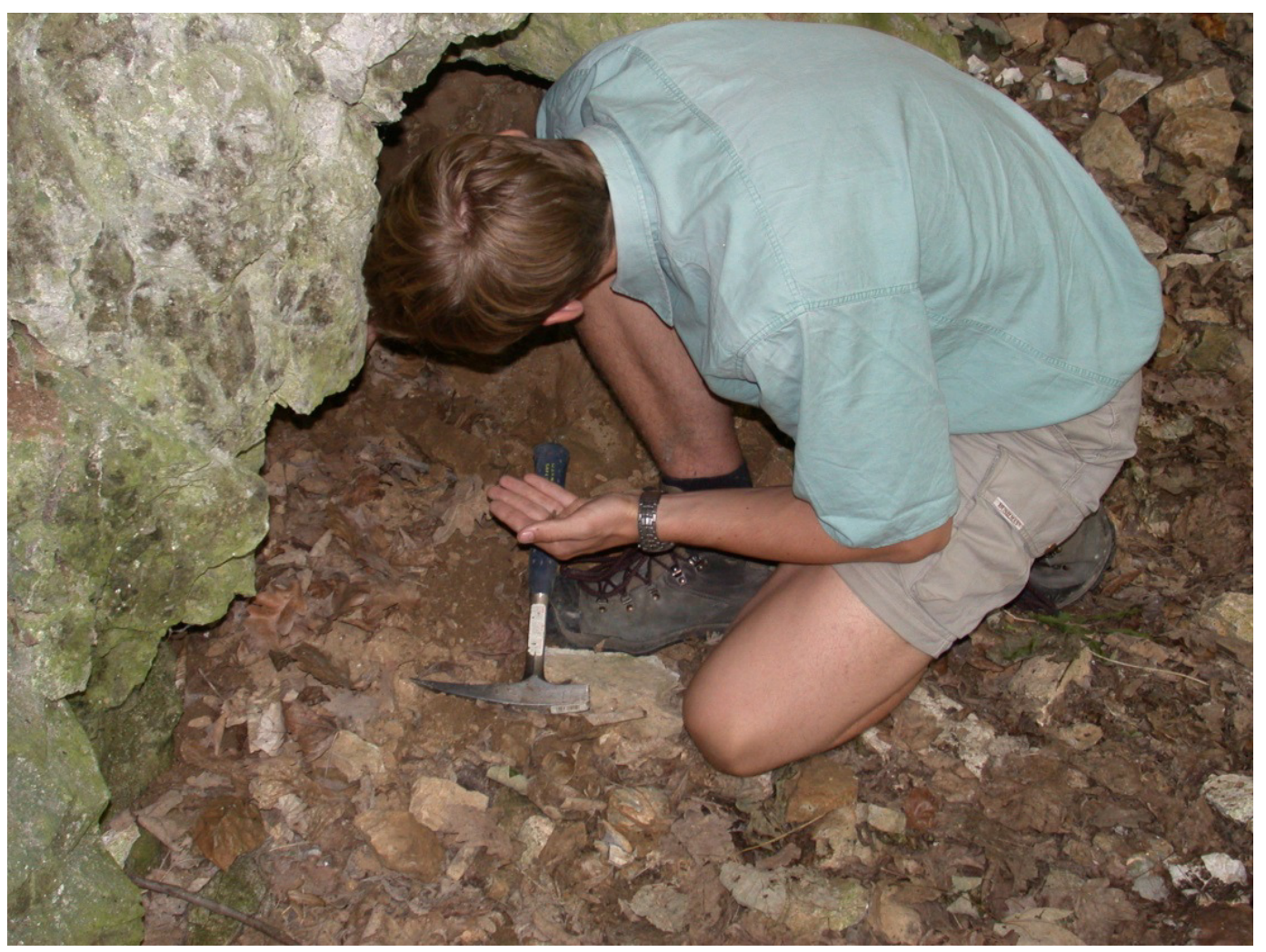

1. ábra. Ősmaradványgyüjtés egy korábbi tehetséggondozó csoport terepi munkája során a bükki Vaskapu-barlangban.

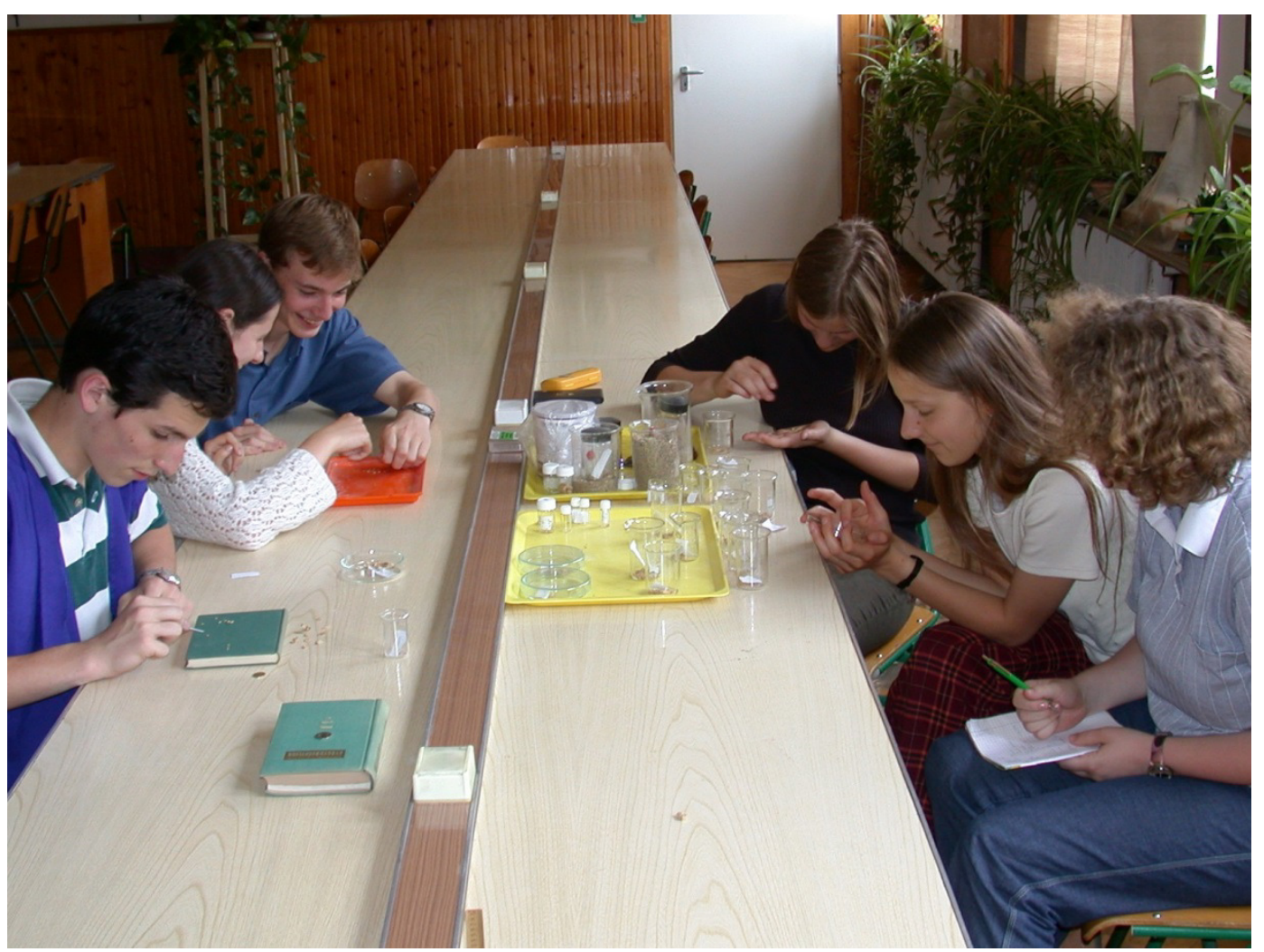

2. ábra. A fenti gyűjtés eredményének feldolgozása az iskola akkori biológia szaktantermében. 


\section{Kutatómunka a Pintér Ernő Tudományos Diákkörben}

\section{a. Kezdeti kutatások}

A Tudományos Diákkör munkája az első időkben leginkább a szakkörvezető (Mészáros Lukács) szakterületéhez kapcsolódott. Először 1994 nyarán csatlakoztunk ahhoz az őslénytani kutatótáborhoz, amelyet Dr. Hír János, a Pásztói Múzeum igazgatója szervezett. Az ezt követő években a Diákkör önálló kutatásokat is végzett ezen a területen (1-2. ábra), amelyek jelentősen hozzájárultak a hajdani élővilág és környezet felderítéséhez (MÉSZÁROS 2004).

Az ősi ökoszisztémák kutatása a későbbiekben is az érdeklődés fókuszában maradt. Munkánk során együttműködtünk az Eötvös Loránd Tudományegyetem Öslénytani Tanszékével és a Magyar Természettudományi Múzeum Őslénytani és Földtani Tárával. Eredményeik bemutatásával az elmúlt csaknem negyed században a diákok több ízben is előkelő helyezéseket értek el pályázatos tanulmányi versenyeken. A munka tudományos színvonalát tekintve nagy előrelépésnek számított, hogy a 20092010. tanévben „Ökoszisztéma változások kutatása a fosszilis bükki és recens alpi faunák összevetésével" című projektünk elnyerte az Útravaló Ösztöndíjprogram, Út a Tudományhoz Alprogram támogatását (3. ábra). A projektre való hivatkozással jelentős tudományos publikációk készültek (MÉSZÁROS 2010, MÉSZÁROS 2011).

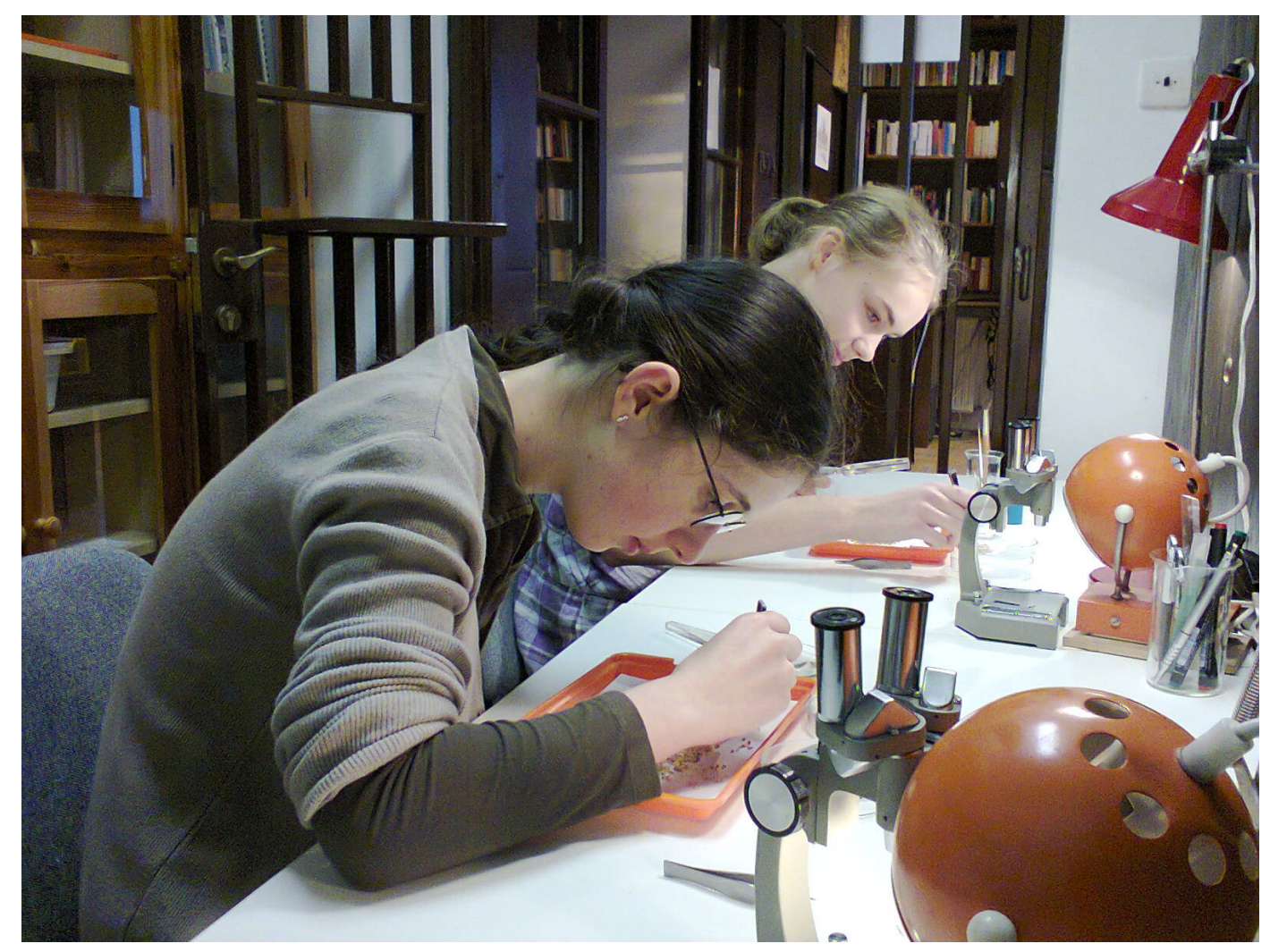

3. ábra. Laboratóriumi munka az UT-2014/2015-0001 projekt során.

Hasonlóan eredményes volt a 2014-15. tanévben futó Út a Tudományhoz projektünk (UT2014/2015-0001) amely a Magyar Tudományos Akadémia, a Magyar Természettudományi Múzeum és az Eötvös Loránd Tudományegyetem közös kutatócsoportjának OTKA K104506 számú, 20132017. évi projektjéhez kapcsolódott. Ennek címe: „Magyarország legjelentősebb középső-pleisztocén szárazföldi lelőhelyének (Somssich-hegy 2, Villány) taxonómiai, tafonómiai, paleoökológiai és 
rétegtani vizsgálata" (PAZONYI et al. 2018). Az OTKA projekt munkáját a diákkör tagjai az ősmaradvány-anyag válogatásával, előzetes meghatározásával és bizonyos csoportok paleoökológiai feldolgozásával segítették. Az eredmények a diákkör munkájára való hivatkozással jelentek meg a publikációkban (MÉSZÁROS 2014, 2015a, 2015b, BOTKA \& MÉSZÁROS 2015).

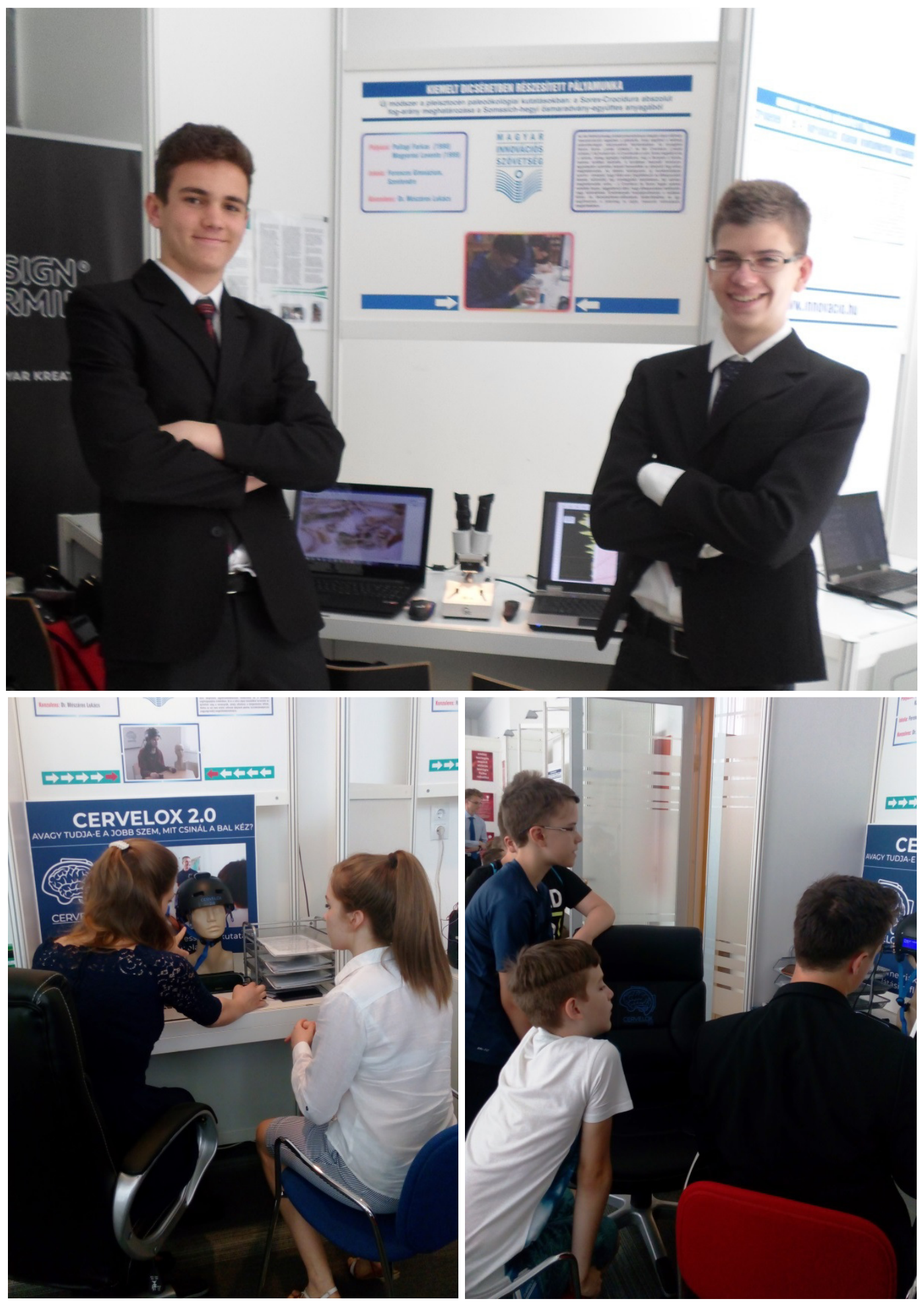

4. ábra. Az UT-2014/2015-0001 projekt ösztöndíjasai 24. Ifjúsági Tudományos és Innovációs Tehetségkutató Versenyen, ahol a „Kiemelten dícséretes kategóriában” végeztek (fent) és a jelen cikkben bemutatott UT-2017-0012 ösztöndíj kutatói az idei (27.) versenyen, ahol első díjat nyertek (lent). 
Ez utóbbi pályázat azért is fontos volt a tehetséggondozó program számára, mert ennek során történt először, hogy diákjaink önálló publikációban mutatták be eredményeiket (FÉLEGYHÁZI \& LENGYEL 2017), valamint 2015-ben ebben a témában indultunk a 24. Ifjúsági Tudományos és Innovációs Tehetségkutató Versenyen, amelynek tapasztalatai megalapozták a jelen cikkben bemutatott projekt sikerességét (4. ábra). Az Innovációs Versennyel kapcsolatos szaktanári teendőket a szerzők közül Trembeczki Mária végezte.

\section{b. A neurobiológiai kutatások megjelenése}

A Pintér Ernő Tudományos Diákkör mentortanára 2015-2020. évi kutatótanári programjának részét képezte az a felmérés, amelynek során a Tudományos Diákkörből egyetemekre került diákokkal készült interjúkon keresztül felmérte, hogy a fiatalok milyen változtatásokat látnának hasznosnak a szakkör müködésével kapcsolatban.

A válaszok alapján az egyik legfontosabb változtatási igény a kutatások témájával kapcsolatban merült fel. A volt diákkörösök túlságosan szüknek találták a paleontológiai-ökológiai szakterületet és szívesen vették volna, ha a témaválasztásban nagyobb szabadságot élvezhenek. Ez az információ vezetett oda, hogy 2016-ben már teljesen a tanulók igényeihez igazítottuk a témákat. A jelen cikkben bemutatott projekt kutatói (Matányi Marianna és Kákonyi Marcell) olyan területet kerestek, amely egyrészt az idegrendszer müködésével kapcsolatos, másrészt jelentős informatikai vonatkozása is van. Ez a kombináció jól illeszkedett a kutatópáros affinitásához és előrevetítette annak lehetőségét, hogy a team-munkában kiválóan kiegészítik egymást.

Az idegrendszerrel kapcsolatos téma egyébként nem idegen iskolánk tehetséggondozó tevékenységétől, hiszen az elmúlt több mint egy évtized során számos tanulónk nyerte el a Ramón y Cajal ösztöndíjat és végzett már gimnazistaként ilyen jellegü kutatásokat az Oxfordi Egyetem vagy a Magyar Tudományos Akadémia neurobiológiai kutatólaboratóriumaiban.

Hogy az idegrendszeri kutatások középiskolai tudományos diákkör keretein belül is megvalósíthatók, azt jól bizonyítja, hogy Matányi Marianna és Kákonyi Marcell első díjat nyert a 27. Ifjúsági Tudományos és Innovációs Tehetségkutató Versenyen és ezzel elnyerték a jogot, hogy két társukkal együtt ők képviseljék hazánkat Dublinban, a szeptemberi "30. EU Contest for Young Scientists” elnevezésủ nemzetközi tudományos megmérettetésen (MATÁNYI \& KÁKONYI 2018).

\section{Pedagógiai vonatkozások}

A tanulók számára a kutatómunka a korszerủ és kritikus szemléletủ infomációgyüjtésbe, a logikus (analitikus és szintetizáló) gondolkodásba és tudományos világszemléletbe jelent bevezetést. Tapasztalatot szereznek a team-munka különféle aspektusairól: az együttmüködő, vagy éppen az irányító szerepről. Legtöbben közülük tudományos pályát választanak. Komoly motivációt jelent számukra, hogy korábbi diákkörösök, már mint sikeres kutatók beszámolnak nekik eredményeikről és az előttük megnyíló lehetőségekröl.

A diákköri nevelés összhangban van az iskola fö elveivel, amelyek között kiemelt helyen szerepel a rendalapító Assisi Szent Ferenc (,az ökológia védőszentje”) szellemében az egész teremtett világ testvérként való szeretetének és tiszteletének átadása. A paleoökológiai kutatásokban a diákok azért dolgoznak lelkesen, mert ezek a vizsgálatok hozzájárulhatnak a jelenleg is zajló környezeti változások pontosabb felderítéséhez, és így a káros következmények megelőzéséhez. Nagyon lelkesíti őket, hogy eredményeikkel áttételesen ,a természet megmentését” segíthetik.

A ferences felfogás még inkább megmutatkozik abban a törekvésben, amellyel a jelen projekt kutatói a segítségre szoruló gyermekek felé fordulnak. Hiszen a kicsinyekre való figyelés és a róluk való gondoskodás még a természet szereteténél is jobban jellemezte Assisi Szent Ferencet. 


\section{A „Cervelox 2.0” projekt bemutatása}

\section{A kutatás előzményei}

Az itt bemutatott projekt kutatói a szentendrei Ferences Gimnázium tanulói. A kutatás a Ferences Ösztöndíjprogram 2016-2017. évi kutatásaként indult el (5. ábra) és az 2017-2018 ösztöndíjas időszakban is folytatódott. Ugyanakkor a kutatás az Útravaló Ösztöndíjprogram Út a Tudományhoz alprogramjában a 2017-2018-as tanévre elnyert UT-2017-0012 számú projektnek is részét képezi. Ebben iskolánk együttmüködő partnere az Eötvös Loránd Tudományegyetem Természettudományi Karának Embertani Tanszéke.

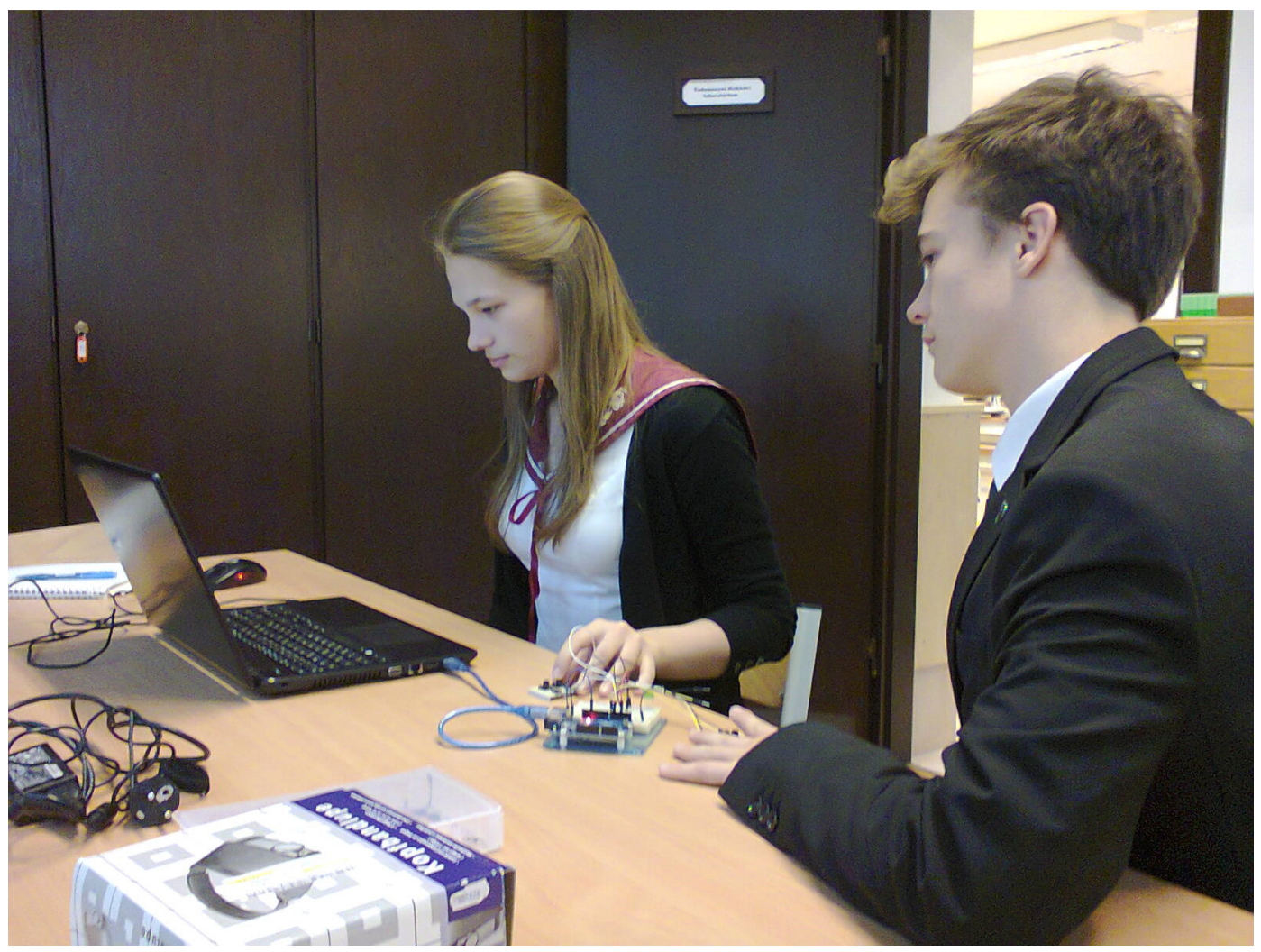

5. ábra. A jelen projekt kutatói munka közben a 2016-2017-es ösztöndíjas időszakban.

A Ferences Ösztöndíjprogram 2016-2017 évi ösztöndíjas kutatásában a kezdeti cél az agyféltekék aszimmetrikus müködésének tanulmányozása volt egy általunk fejlesztett reflexidő mérő berendezés (hardware és software) segítségével. Ennek során a kísérleti személyek a jobb, illetve a bal látóterükben felvillanó fényingerre nyomógomb lenyomásával válaszoltak, és ennek a válasznak az idejét regisztráltuk. Vizsgáltuk például a jobb és balkezesek, a fiúk és a lányok közötti különbségeket (HÁMORI 2005). A különböző feladatok közül volt olyan, amelynél az ingerület áthaladt a corpus callosumon, és olyan is, melynél nem érintette a kérgestestet (SZENTÁGOTHAI \& RÉTHELYI 2006). Egyes személyeknél a keresztezett reflex esetében az átlagostól való jelentős eltéréseket tapasztaltunk. Eredményeinkről az iskolai fejlesztőpedagógus véleményét is kikérve arra a következtetésre jutottunk, hogy az eltérést mutató tanulók fôként olyanok lehetnek, akik (pl. a kérgestest múködési zavarai miatt) mozgáskoordinációs, vagy egyéb fejlesztésre szorulnak. Ezért a 2017-2018-as tanévben ezen a vonalon szerettük volna folytatni a munkát. 


\section{A kutatás célja}

A köznevelésbe kerülő iskolások között vannak olyan tanulók, akiknek a különleges nevelési igényük abból fakad, hogy a két agyféltekét összekötő kérgestest (corpus callosum) müködésének zavarai miatt a két agyfélteke közötti kapcsolat nem megfelelő gyorsasággal jön létre. Az ilyen tanulók nemcsak mozgáskoordinációs problémákkal küzdenek (pl. a testnevelési órákon), hanem az írás, olvasás és rajzolás is zavart szenved náluk (GYARMATHY 2009). Emiatt sok, ilyen tevékenységre épülő tanulási folyamatuk nehézségekbe ütközik. Problémáik diagnosztizálásakor nagyon fontos a minél korábbi felismerés, hogy időben megkaphassák a fejlesztő pedagógus segítségét.

Az általunk kifejlesztett, eddig sehol nem alkalmazott módszer egyszerüsége és gyorsasága lehetővé tenné, hogy akár minden, iskolába kerülő kisgyermeken elvégezhessünk egy tesztet, amely alapján kiszürhetjük azokat, akiknek további, részletes vizsgálatokra van szükségük a két agyfélteke nem megfelelő együttmüködésének felderítése érdekében, ezzel segítve a megfelelő időben megkezdett fejlesztést.

A kutatás során egy olyan készülék kifejlesztését és tesztelését terveztük, amely alkalmas lehet az említett problémák minél korábbi kiszürésére és továbbfejlesztés esetén akár konkrét rendellenességek kiegészítő diagnosztikai eszközévé is válhat. A berendezést „Cervelox”-nak neveztük el. Ez a szó a cerebrum (agy) és a velox (gyors) latin kifejezésekből származik, és arra utal, hogy a vizsgálatokat bizonyos agyi reflexek gyorsasága alapján végeztük. A készülék nevében a 2.0 jelzés arra utal, hogy az előző tanévben már elkészítettük és teszteltük a berendezés első, próbaváltozatát, a „Cervelox 1.0”-t (6. ábra).
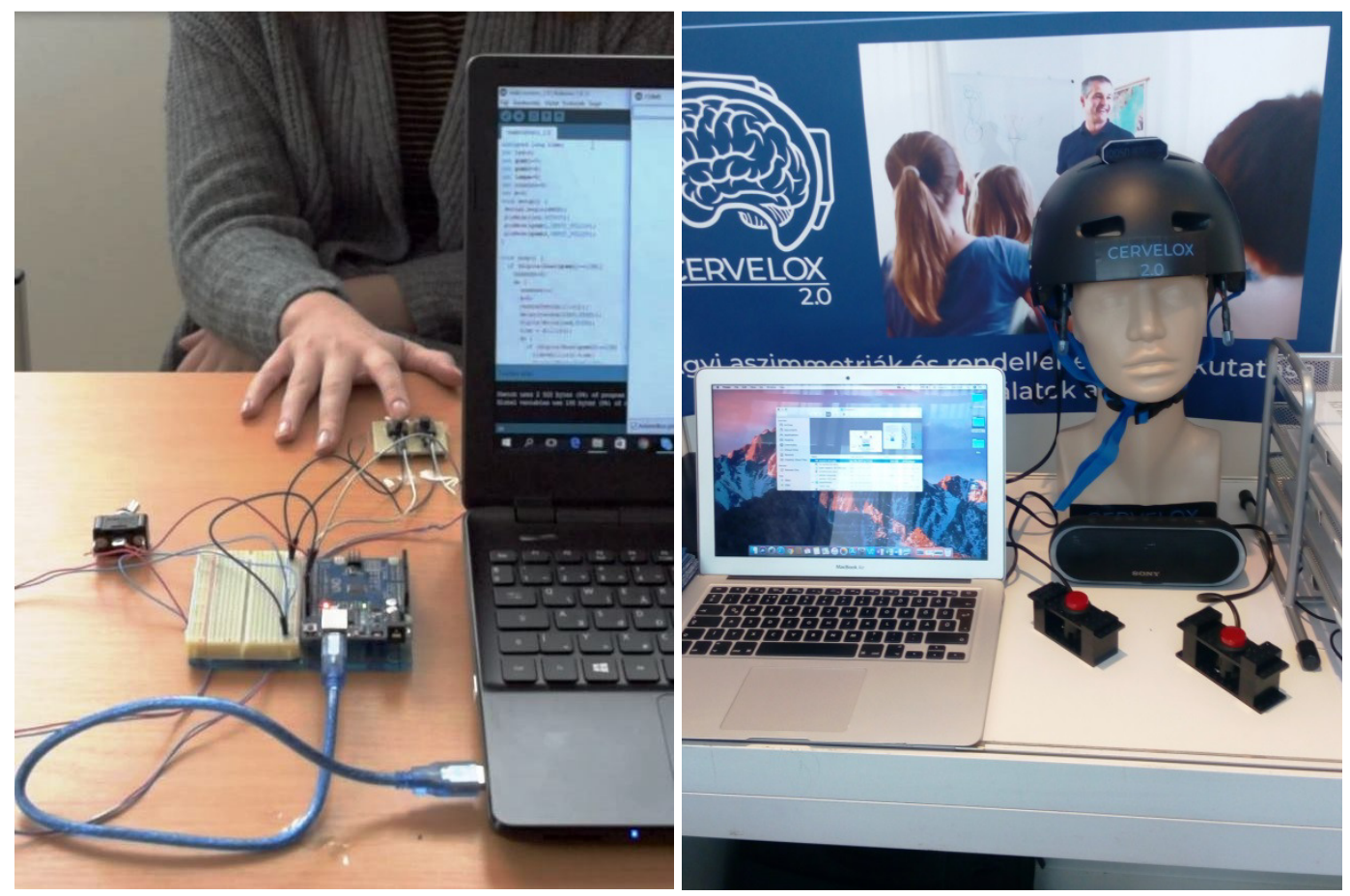

6. ábra. A 2016-17-es ösztöndíjas időszakban elkészült Cervelox 1.0 (balra) és a 2018-ra kifejlesztett, a 27. Ifjúsági Tudományos és Innovációs Tehetségkutató Versenyen első díjat nyert Cervelox 2.0 berendezés (jobbra).

A méréshez szükséges technikai berendezést, valamint az abba épített vezérlő és adatfeldolgozó software-t kutatócsoportunk alkotta meg. A kész eszköz tesztelését úgy szándékoztuk elvégezni, hogy az említett problémákkal korábban - más módszerrel - már diagnosztizált gyerekeknél megmérjük a 
kérgestesten keresztül megvalósuló reflexek sebességét és összevetjük a saját, kérgestestet nem érintő reflexeikkel. Kontrollcsoportként az iskolánkba járó, az említett problémákkal nem küzdő diákok egy, azonos korosztályból összeállított csoportját terveztük felmérni.

\section{A vizsgálatok élettani alapjai}

Egy reflex megvalósulása során az ingerület a környezetből érkező ingertől a kiváltott hatásig (a reflexválaszig) a reflexíven fut végig. Az általunk vizsgált egyszerü látási reflex esetében ez a következő utat jelenti:

- a szem egyik oldali látóteréből a kép a retina ellenkező oldalára vetül,

- a látóidegen végighaladva, az ideg részleges átkereszteződésénél a látótérrel ellentétes oldali agyféltekébe jut (afferens szár),

- a köztiagy talamusz nevü részében átkapcsol,

- a látótérrel ellentétes oldali nyakszirti lebeny látókérgébe kerül,

- ugyanezen oldali homloklebeny mozgatókérgébe jut,

- majd onnan a mozgatópályákon átkereszteződve az ellenkező oldalon, a gerincvelőben átkapcsolva a mozgató utasítás a kézbe fut (efferens szár).

Keresztezett reflex esetén a reflexív annyival bonyolultabb, hogy az ingerület az adott oldali látókéregből a kérgestesten keresztül az ellentétes oldali mozgatókéregbe jut, és onnan folytatódik tovább a folyamat. Ha tehát a kérgestesten keresztüli kapcsolat zavart szenved, akkor a keresztezett reflex ideje jelentősen megnő az egyszerü reflexhez képest (KOMOLY \& PALKOVITS 2015).

Kutatásaink során minden személynél négy reflexutat vizsgálunk, amelyek közül kettő a kérgestest érintésével, míg kettő a kérgestest érintése nélküli reflexíven zajlik (MOTZ et al. 2012). A fényingerek csak az egyik látóteret érik és csak egy kézzel, egy gomb lenyomásával kell rájuk válaszolni.

- Jobb oldalról érkező fény hatására jobb kézzel végrehajtott válasz: Jobb szem látóterének külső perifériájáról az ingerület a bal agyfélteke látókérgébe fut. Innen átkapcsol a bal oldali mozgató kéregbe, ahonnan az efferens szár a jobb kéz izmaihoz viszi az ingerületet. Ekkor a vizsgált személy lenyom egy gombot.

- Jobb oldalról érkező fény hatására bal kézzel végrehajtott válasz: Jobb szem látóterének külső perifériájáról az ingerület a bal agyfélteke látókérgébe fut. Innen a jobb oldali mozgató kéregbe kapcsol át a kérgestesten keresztül, ahonnan az efferens szár a bal kéz izmaihoz viszi az ingerületet és a vizsgált személy lenyomja a gombot.

- Bal oldalról érkező fény hatására bal kézzel végrehajtott válasz: Bal szem látóterének külső perifériájáról az ingerület a jobb agyfélteke látókérgébe fut. Innen átkapcsol ugyanazon agyfélteke mozgató kéregbe, ahonnan az efferens szár a bal kéz izmaihoz viszi az ingerületet és a vizsgált személy lenyomja a gombot.

- Bal oldalról érkező fény hatására jobb kézzel végrehajtott válasz: Bal szem látóterének külső perifériájáról az ingerület a jobb agyfélteke látókérgébe fut. Innen a kérgestesten keresztül a bal oldali mozgató kéregbe kapcsol át, ahonnan az efferens szár a jobb kéz izmaihoz viszi az ingerületet és a vizsgált személy lenyomja a gombot.

\section{A vizsgálóberendezés és a vizsgálati módszer}

\section{a. A Cervelox 2.0 méröberendezés felépítése}

A hardware alapja egy „freestyle” bukósisak, melybe beépítettük a berendezés komponenseinek nagyrészét. A sisak hátulján található a Cervelox 2.0 eszköz lelke, egy Raspberry Pi 3 model B típusú 
mikroszámítógép, melyen a Debian névre hallgató linux disztribúció tölti be az operációs rendszer szerepét. Ezen fut a - kutatócsoportunk által írt - software, mely a mérési folyamatokat vezérli. Az áramellátásáért egy 10050 mAh-s akkumulátor felel. Ez a megfelelő súlyeloszlás biztosítása érdekében a sisak tetején helyezkedik el. A bukósisakon található továbbá két, állítható helyzetű LED. Ez a két lámpa villan fel a mérés folyamán, amit a vizsgált személynek figyelnie kell. A sisak oldalába egy 16x4 cm-es, háttérvilágítású kijelző van építve, amelyen a vizsgálat folyamán nyomon követhető, hogy fut-e a program és melyik stádiumban tart a mérés, valamint látható rajta a vizsgált személy kódja és az aktuálisan mért reflexidő érték is (7. ábra).

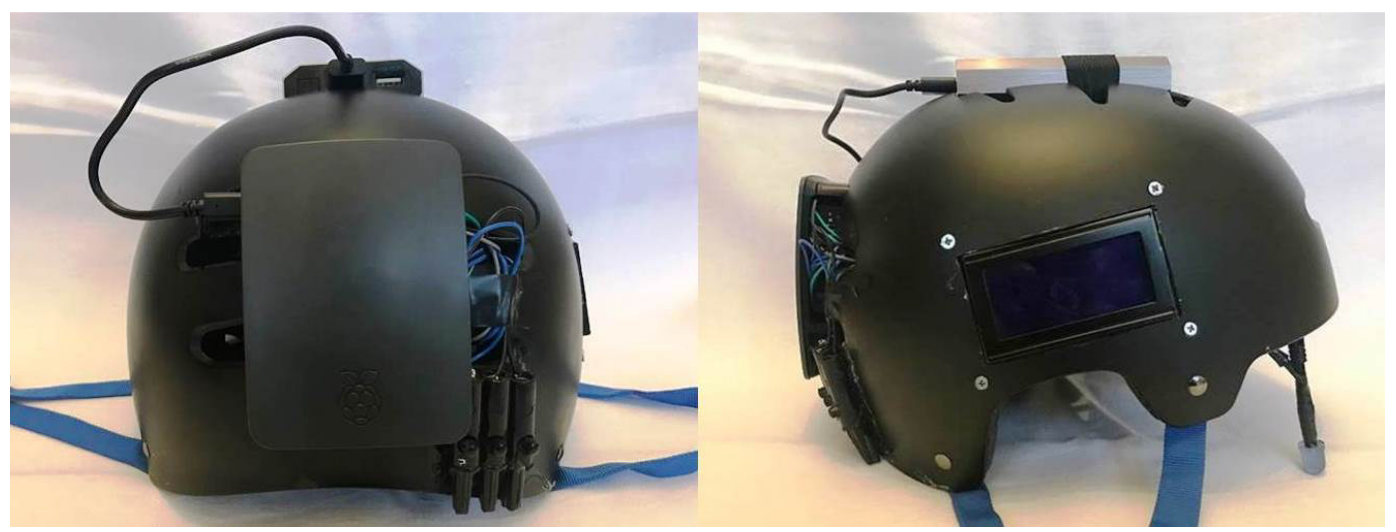

7. ábra. A Cervelox 2.0 berendezés sisakrésze hátsó (balra) és oldalsó (jobbra) nézetből.

A Cervelox 2.0 berendezés következő eleme egy karosszék, melynek karfájába vannak építve azok a gombok, amelyekkel a vizsgált személy a LED kigyulladására reagál. A gombok és a sisak között kábellelösszeköttetés van. Az eszköz építése során kerestünk ugyan olyan megoldást, ami révén a gombok vezeték nélkül kommunikálhattak volna a berendezés többi részével, de egyelőre nem találtunk erre alkalmas technológiát.

A Raspberry Pi mikroszámítógép vezérlésére egy Apple Macbook Air (2017) típusú laptopot használunk, amely a VNC Viewer program segítségével kommunikál az ugyanazon hálózatra felcsatlakoztatott Raspberry Pi-vel, VNC vezeték nélküli kapcsolaton keresztül.

A hardware része továbbá egy Sony SRS-XB20 bluetooth hangszóró és egy Sony MDR-ZX220BT bluetooth fejhallgató. Az adott szituációnak megfelelően, ezek valamelyikén át hallja a vizsgált személy a - hangfelvételen rögzített - instrukciókat.

A hardware-t vezérlő software-t Python 2 nyelven írtuk. Ez a program vezérli az eszköz komponenseit: a LED-eket, a kijelzőt, a gombokat, a hangfalat és a fejhallgatót. Az adatokat valós időben rögzíti, majd eltárolja a 4x25 értéket a címsorokkal együtt, végül xlsx, illetve biztonsági másolatként txt formátumban is menti. Az elmentett eredményeket a mérés lefutása után kielemzi: szórást, átlagot, keresztezési indexet, minimumot és maximumot számol, majd elkészíti azokat a grafikonokat egy excel fájlba, amelyek segítségével levonhatók lesznek a megfelelő következtetések.

\section{b. A mérőberendezés alkalmazása a vizsgálatok során}

A vizsgálat kezdetekor a vizsgálati személy átadja a mérést vezető kutatóknak az anonimitást biztosító kódját, majd beül a székbe, a fejére teszi a sisakot és a kezeit a gombokra helyezi. A programot elindítjuk az erre szolgáló parancsikon segítségével, majd a felugró terminál-ablakban megjelenő utasításnak megfelelően bevisszük a kódot a rendszerbe. Ezt követően elindul a hangfelvétel, ami elmagyarázza a vizsgált személynek a feladatot. A mérés folyamán mindvégig egy, 
vele szemben lévő pontot kell néznie, ezzel biztosítva a látóterek szétválasztását. A mérés négy szakaszból áll. Az aktuális feladatot minden szakasz előtt elhangzik. Ha nem merült fel kérdés a feladattal kapcsolatban, elindítjuk az első szakaszt. Ennek során a jobb kéz felőli LED villan fel egymás után huszonötször, random időközönként, 1-5 másodperc közötti időintervallumban. A LED minden felvillanására a jobb oldali gomb megnyomásával kell reagálnia, a lehető legrövidebb időn belül. A program minden eredményt rögzít és felvezeti egy excel táblázatba. Az első szakaszt még három sorozat követi. Ezek során a bal oldali LED felvillanására kell bal kézzel, majd a jobb oldali LED-re bal kézzel, végül pedig a bal oldali LED-re jobb kézzel kell reagálnia a vizsgált személynek. A negyedik szakasz végeztével a program elmenti a létrehozott xlsx és txt fájlokat, kielemzi az eredményeket és ezzel befejeződik a mérés.

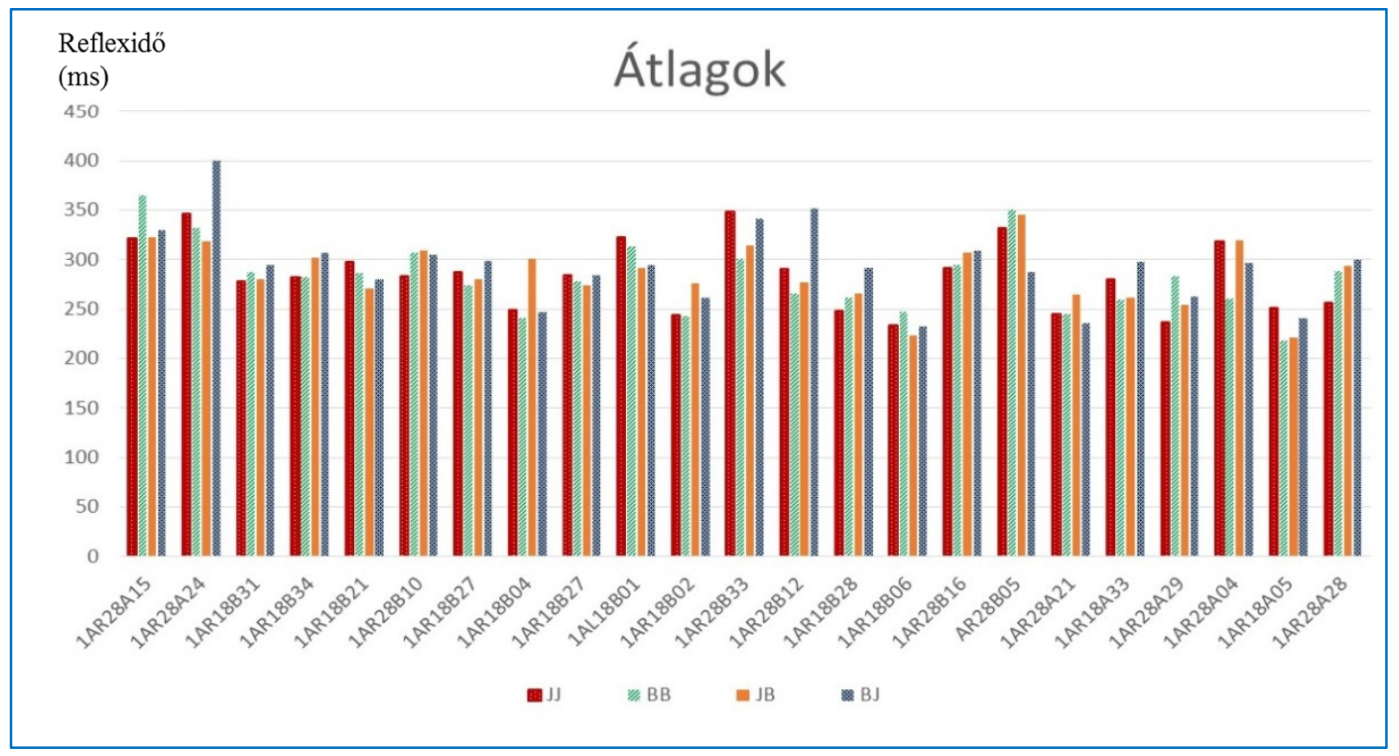

8. ábra. A kontrollcsoport mérési eredményei (ezredmásodpercben);

JJ: jobb szem-jobb kéz, BB: bal szem-bal kéz, JB: jobb szem-bal kéz, BJ: bal szem-jobb kéz.

\section{c. A kontroll-mérések elvégzése}

A vizsgálatok megkezdése elött kontrollméréseket végeztünk, hogy legyenek olyan értékeink, amelyekhez a rendellenes reflexidőket viszonyítani tudjuk. A kontrollcsoport tagjai iskolánk tanulói közül kerültek ki. A mérések során úgy tudtuk biztosítani a teljes anonimitást, hogy a hozzánk járó 8. évfolyam önként jelentkező diákját felmértük, de az eredményeket nem nevekhez, hanem egy speciális kódhoz rendeltük. Ezt a kódot és a hozzá tartozó mérési eredményeket egyedül iskolánk fejlesztőpedagógusa és a mentortanár tudta azonosítani a valós személyekkel. A kódokra csak azért volt szükség, hogy a mentortanár a fejlesztőpedagógus segítségével ki tudja emelni számunkra az adathalmazból azoknak a gyerekeknek az értékeit, akik a nevelési tanácsadó véleménye szerint speciális nevelési igényủek. Így a kontrollcsoport mérete végül 23 föt tett ki (8. ábra).

A kísérleti személyeknél minden reflexúthoz 25 mérés tartozott. Az így kapott adatokat személyenként és reflexutanként átlagoltuk és minden személynél kiszámítottuk az ún. „keresztezési index”-et. A „keresztezési index” a vizsgált személy egyenes irányú (jobb szem-jobb kéz és bal szembal kéz) reflex-eredményeinek átlaga elosztva a keresztezett irányú (jobb szem-bal kéz és bal szemjobb kéz) reflexidők átlagával. Várakozásainknak megfelelően a legtöbb esetben 1,00-től némileg eltérő, de ahhoz közelítő értéket kaptunk. Ezután a vizsgálati diagramon ábrázoltuk azt a sávot, amelyet a kontrollcsoport keresztezési indexeinek minimum $(\mathbf{0 , 8 8 3 5})$ és maximum $(\mathbf{1 , 0 8 3 5})$ értékei 
határoztak meg (9. ábra). A kontrollcsoport keresztezési indexének szórásértéke (0.0593) a csoport homogenitására utal.

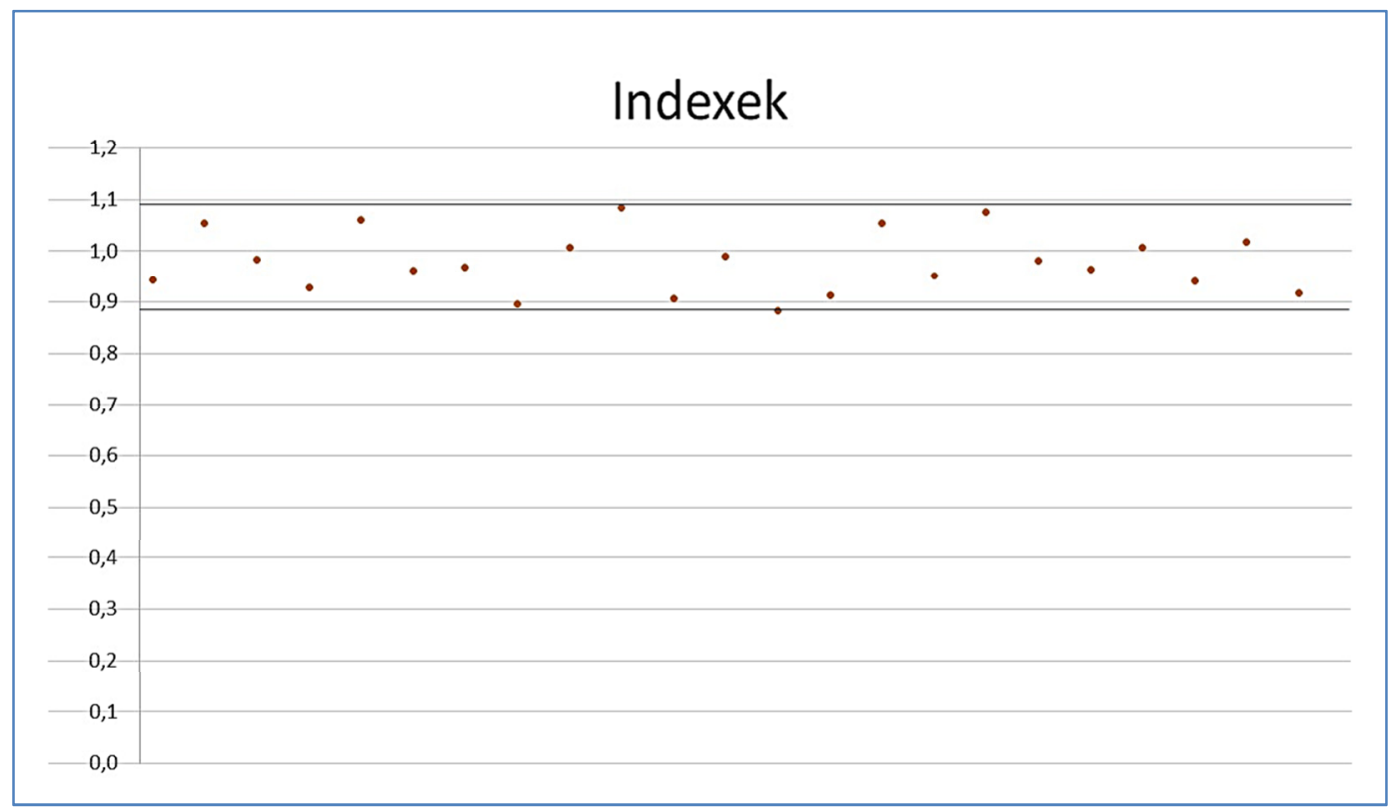

9. ábra. A kontrollcsoport keresztezési indexei által kijelölt „,normál sáv”.

\section{d. A berendezés tesztelése speciális nevelési igényü személyeken végzett mérésekkel}

A kutatás további részében olyan, az iskolánkba járó tanulók értékeit vontunk be a vizsgálatokba, akik a nevelési tanácsadó vizsgálatai alapján - az általunk tanulmányozott müködéshez kapcsolható speciális nevelésre, fejlesztésre szorulnak. A „„” pontban leírt vizsgálati metódus szerint az ő adataikat is anonim módon kezeltük.

A mérések során azt vizsgáltuk, hogy a speciális nevelési igényü személyek keresztezési index értékei illeszkednek a kontrollcsoport értékei által kijelölt sávba, vagy ki tudunk-e mutatni valamilyen eltérést. A kiértékelés során a mérési eredmények szóródását is figyelembe vettuik.

A tapasztalatok alapján (lásd az „Eredmények” címü fejezetben) valószínünek tünt, hogy az elkészített vizsgálóberendezés alkalmas a corpus callosum müködési zavarainak felderítésére. Szakirodalmi áttekintés és neurológus szakemberekkel történt konzultáció alapján úgy gondoltuk, hogy a diagnosztikai alkalmazhatóság felderítésére a kérgestest fejlödési zavarai miatt létrejött corpus callosum agenesia betegségben (LÁBADI \& BEKE 2016) szenvedő személyeken lenne legcélszerübb méréseket végezni. Az ilyen betegek ugyanis - a kérgestest teljes vagy részleges müködéskiesése miatt - nyilvánvalóan rosszabb eredményeket mutatnának a keresztezett, mint az egyenes reflexek esetén (KOMOLY \& PALKOVITS 2015). Az ilyen betegekhez kapcsolódó vizsgálatok érdekében több egészségügyi intézetet és szakembert is megkerestünk. Sajnos a kapcsolat megtalálása igen sok időt vett igénybe, mert egyes esetekben a megkeresett intézményben nem volt megfelelö számú beteg személy, máskor pedig a szakemberek éppen a sok beteg miatt nehezen találtak időt a velünk való foglalkozásra. Ez a projekt menetében jelentős késést okozott. Végül a Semmelweis Egyetem, I. sz. Szülészeti és Nőgyógyászati Klinikáján, Dr. Beke Anna docens asszony szíves segítsége és szakmai támogatása lehetővé tette, hogy elinduljon az a folyamat, melynek során corpus callosum agenesiás gyermekekkel is találkozhatunk és reflexeiket felmérhetjük. 


\section{Eredmények}

A mérések során kontrollként először két tanulási problémákkal nem küzdő diák reflexidejét mértük fel. Várakozásainknak megfelelően keresztezési indexük (0,9818 és 1,0067) a kontrollcsoport minimum- és maximumértékei által meghatározott sávba $(\mathbf{0 , 8 8 3 5 - 1 , 0 8 3 5})$ illeszkedtek (10. ábra).

Ezután egy olyan tanuló értékeit vizsgáltuk, akinél a nevelési tanácsadó figyelemzavart állapított meg, a szakirodalmi adatok (GYARMATHY 2009) alapján ugyanis ilyen esetben is problémás a két agyfélteke koordinált müködése. Az ő keresztezési indexe (0,7828) jóval a normál sáv alatti területre került (10. ábra). Ezt követően egy Asperger-szindrómás diák értékeit tanulmányoztuk, akinek a keresztezési indexe a kontrollcsoporténál jóval magasabb volt $(\mathbf{1 , 2 8 2 4})$. Ö tehát a keresztezett reflexek esetében jobban teljesített, mint az egyenes reflexeknél (10. ábra). Ez azért is érdekes, mert átlagon felüli iskolai teljesítményü diákról van szó és bizonyos adatok nem zárják ki, hogy a corpus callosum kivételesen jó müködése összefüggést mutathat a szellemi képességgel (MEN et al. 2014).

További eredményként megállapítottuk, hogy amíg a figyelemzavaros diák keresztezett reflexértékei $(\mathbf{0 , 1 7 1 2})$ feltünően nagy szórást mutattak a saját egyenes reflexidejéhez képest $(\mathbf{0 , 0 4 4 3})$, addig az Asperger-szindrómás személy egyenes irányú reflex értékei voltak nagyobb szórásúak $(\mathbf{0 , 0 7 7 0})$ a keresztezett reflexekhez képest $(\mathbf{0 , 0 4 2 4})$ (11. ábra).

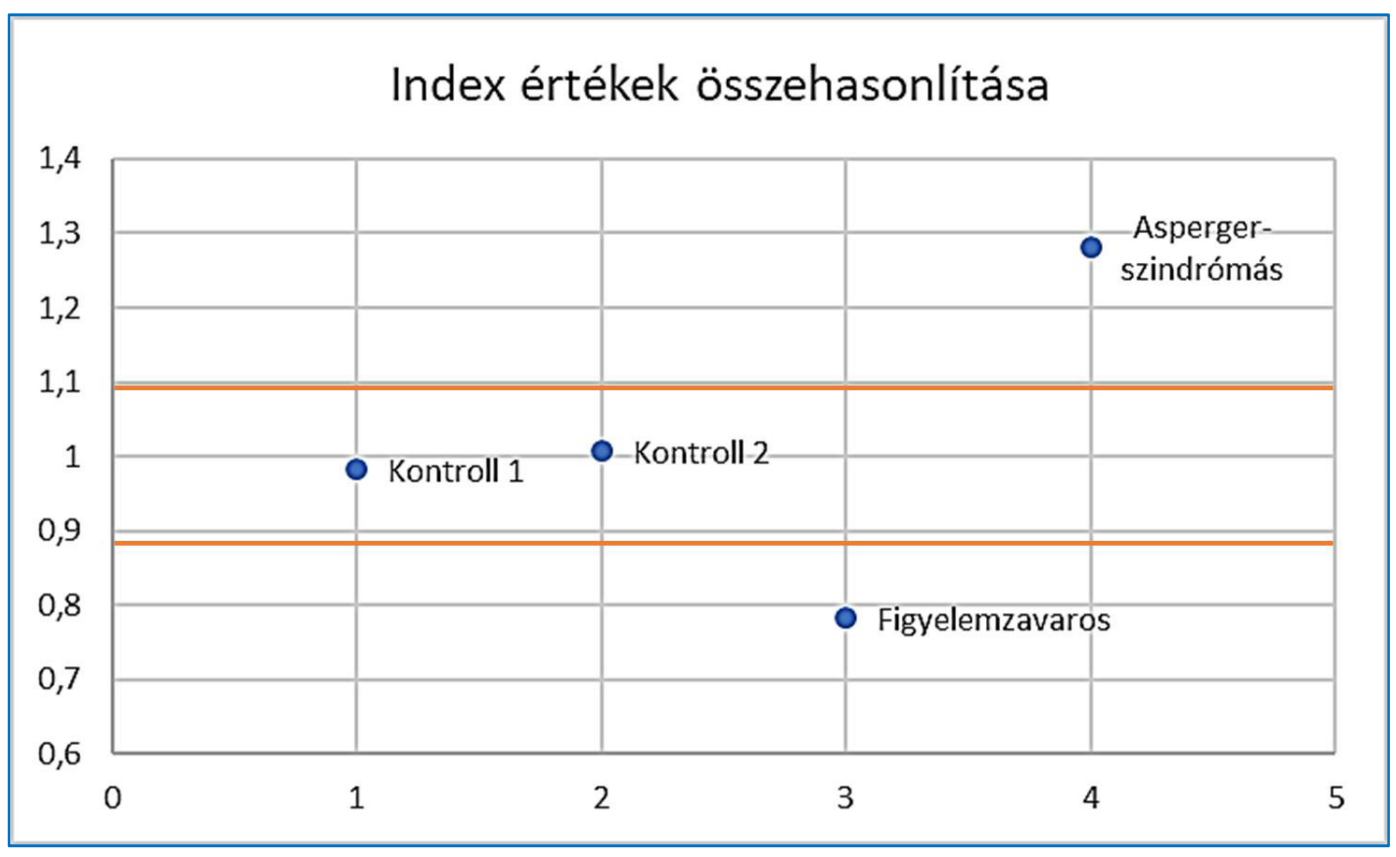

10. ábra. Vizsgált személyek keresztezési indexeinek viszonya a „normál-sávhoz” (egészséges személyek, figyelemzavaros tanuló és Asperger-szindrómás tanuló).

A corpus callosum dysgenesiás és agenesiás betegekkel kapcsolatban - a korábban említett okokból - eddig csak igen kevés eredményről számolhatunk be. Az eddigiek alapján valószínűnek tủnik, hogy különbséget tudunk kimutatni egészséges és beteg személyek között (12. ábra). A Semmelweis Egyetem I. sz. Szülészeti és Nőgyógyászati Klinikáján Dr. Beke Anna docens asszony vállalta, hogy a továbbiakban megszervezi és irányítja a klinikai kutatások lefolytatását, de mivel ezek hosszabb időt vesznek igénybe, a jelen cikkben eredményekről még nem számolhatunk be. 


\section{6. Összegzés}

Kutatásaink eredményeit összegezve megállapíthatjuk, hogy sikerült egy olyan berendezést építenünk, amellyel megbízhatóan el lehet különíteni a corpus callosumot érintő reflexút válaszidejét az egyszerübb lefutású reflexekétől. Ez a készülék a későbbiekben alapját képezheti egy olyan diagnosztikai eszköznek, amely egyszerü és olcsó vizsgálatot tesz lehetővé a kérgestest müködési zavarainak korai kiszürésére. Sikerült elvégezni olyan kontrollméréseket, amelyek alapján megállapítottuk, hogy az általunk kidolgozott „keresztezési index” értékeinek milyen elvárható határértékei vannak egészséges személyeknél.
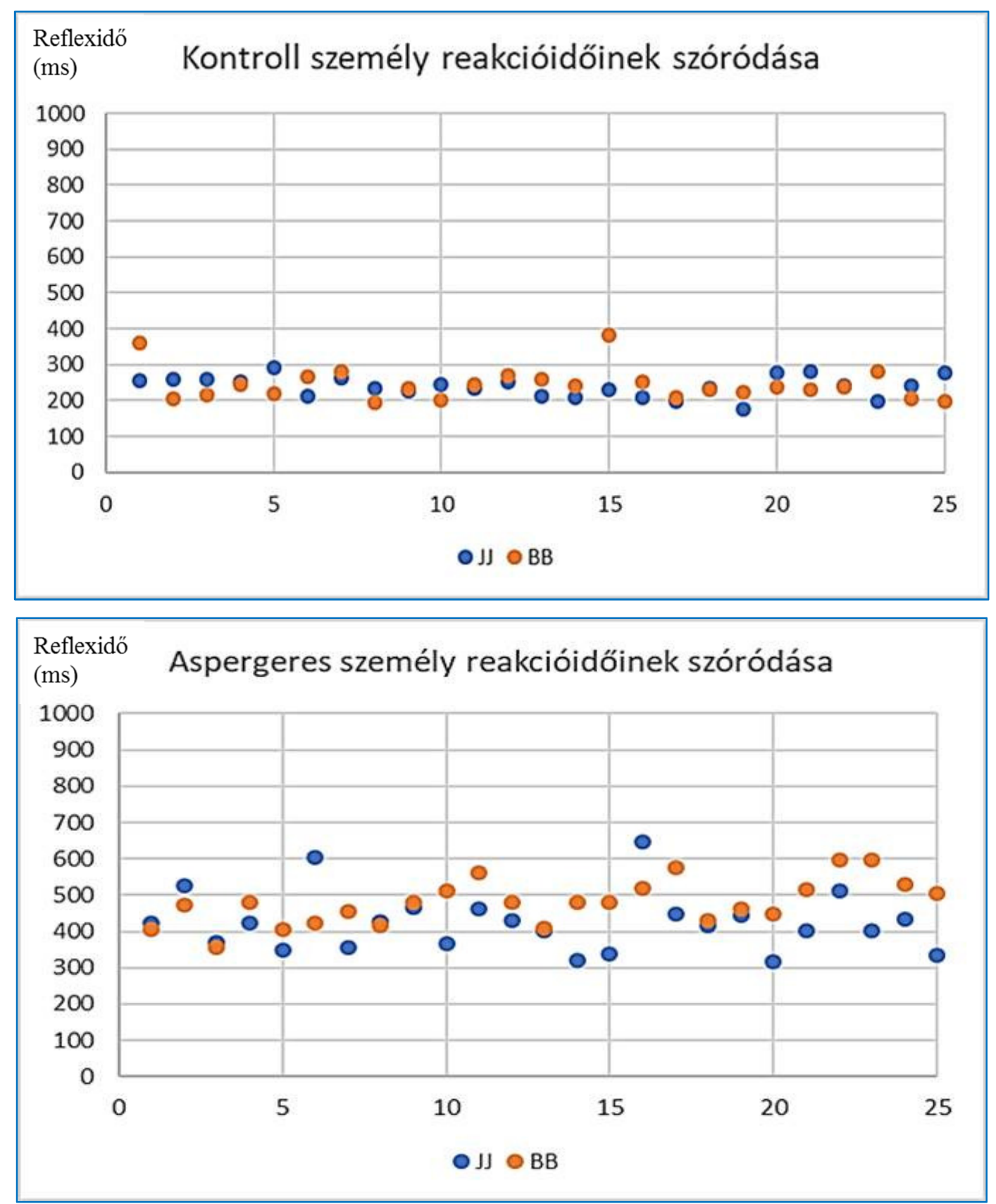

11. ábra. Kontrollszemély (fent) és Asperger-szindrómás személy (lent) egyenes irányú reflexértékeinek szóródása (ezredmásodperc); JJ: jobb szem-jobb kéz, BB: bal szem-bal kéz. 
Különleges nevelési igényü diákokon végzett mérések alapján valószínüsítettük, hogy a figyelemzavaros tanulók keresztezési indexe a normál sáv alatti értéket mutat. Esettanulmányaink alapján azt tapasztaltuk, hogy a figyelemzavaros gyerekek keresztezett értékei nagy szórást mutattak, míg az Asperger-szindrómás személynél ez a nagy szórás az egyenes értékeknél jelentkezett, és nála az adatok a corpus callosum átlag feletti kapacitását jelezték.

Más módszerekkel már egyértelmủen diagnosztizált corpus callosum agenesiás és dysgenesiás betegeken végzett klinikai vizsgálatainkat a kutatás eddigi szakaszában még nem volt lehetőségünk lezárni és a méréseket statisztikusan feldolgozni. Ezért annak megállapítását, hogy vizsgálati eszközünk pontosan milyen problémák kiszürésére alkalmas, a klinikai vizsgálatok lezárulása utáni feladatunknak tekintjük.
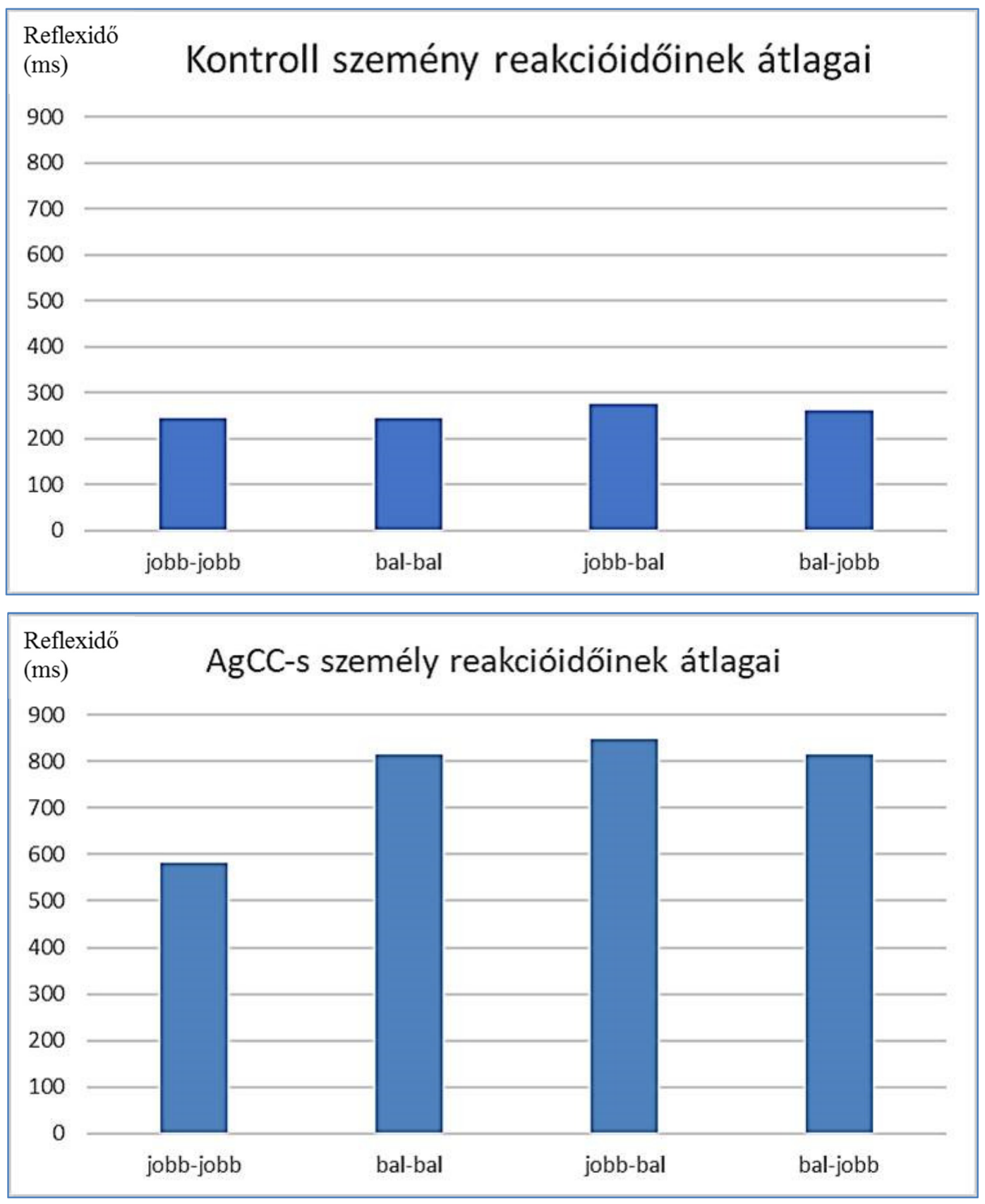

12. ábra. Kontrollszemély (fent) és corpus callosum agenesiás (AgCC) személy (lent) reakcióidőinek átlaga (ezredmásodperc). 
Berendezésünk diagnosztikai eszközzé való fejlesztése hiánypótló lenne, mert eddig nincs olyan müszer, amely lehetővé tenné a corpus callosum zavarainak egyszerü és gyors felismerését. A fejlesztést azért tartjuk nagy jelentőségünek, mert számos olyan kisgyermek van, akik kérgestesti problémák késői felismerése miatt nem jutnak hozzá időben a fejlesztéshez.

Szakorvosi vizsgálat csak a szembeötlően nagy hiányosságal küzdő gyermekek esetén történik meg rövid időn belül. Berendezésünk alkalmas a rizikócsoportba tartozó gyermekek kiszürésére, az eredmények alapján fejlesztőpedagógiai vagy szakorvosi vizsgálat javasolható. Alkalmazása olyan olcsó és egyszerü, hogy akár minden kisgyermeken ajánlatos lenne elvégezni a tesztet. Ez lehetőséget nyújtana a felzárkózásra azok számára is, akiknél a kevésbé feltünően jelentkező tünetek miatt csak későn vagy egyáltalán nem kezdenék el a kezelést vagy fejlesztést, és emiatt jóvátehetetlenül lemaradnak a fejlődésben, így hátrányos helyzetbe kerülnek.

\section{Köszönetnyilvánítás}

Kutatómunkánkhoz sok segítséget kaptunk a szentendrei Ferences Gimnáziumtól. Külön is szeretnénk kifejezni köszönetünket Bécser Róbert igazgató úrnak a támogatásért, Csányiné Tóth Erzsébetnek a gazdasági háttérmunkáért, Ökördi Réka és Berényiné Parti Krisztina tanárnőknek a szakmai segítségért, valamint Szentendrey Péter tanár úrnak, Bíró Bertalannak és Dr. Sergyán Szabolcsnak a technikai és informatikai segítségért.

Az együttmüködésért, a hasznos tanácsokért és a konzultációkért hálával tartozunk Vellainé Dr. Takács Krisztinának (Eötvös Loránd Tudományetem, Embertani Tanszék), Dr. Kelemen Annának (Semmelweis Egyetem, Pető András Kar), Prof. Dr. Nagy Zoltánnak és Prof. Dr. Óváry Csabának (Országos Klinikai Idegtudományi Intézet), Prof. Dr. Ormos Pálnak (Magyar Tudományos Akadémia, Szegedi Biológiai Kutatóközpont) és Dr. Ábrahám Lászlónak (National Instruments Hungary Kft).

Különös szeretnénk megköszönni a támogatást Dr. Beke Annának (Semmelweis Egyetem, I. sz. Szülészeti és Nőgyógyászati Klinika), akinek kedves és lelkes segítsége, szervezőmunkája és rendkívül értékes neurológiai szakmai tanácsai nélkül munkánk egyáltalán nem léphetne klinikai szakaszba.

A kutatást az Útravaló Ösztöndíjprogram Út a Tudományhoz alprogramjának UT-2017-0012 számú projektje és a Ferences Ösztöndíjprogram (T1 - Alkotói/Kutatási Kategória) támogatta.

\section{Irodalom - References}

BotKA D. \& MÉSZÁros L. (2015): A Somssich-hegy 2-es lelőhely (Villányi-hegység) alsópleisztocén Beremendia fissidens (Mammalia, Soricidae) maradványainak taxonómiai és paleoökológiai vizsgálata. Földtani Közlöny, 145(1): 73-84.

FÉLEGYHÁZi L. \& LENGYEL, S. Á. (2017): Meglepetés sztyepp a Pleisztocénben: Paleoökológiai vizsgálatok a Somssich-hegy 2-es lelőhely cickányai alapján. Természet Világa, 148(5): Melléklet VXXII-LXXV.

GYARMATHY É. (2009): Neurológiai eredetü teljesítményzavarok. In: KISS SZ. (szerk): Az iskolai beilleszkedés problémák felismerése, prevenciója és terápiája. Kolozsvári Egyetem Kiadó. pp. 4556.

HÁMORI J. (2005): Az emberi agy aszimmetriái. Dialog Campus Kiadó, Budapest.

Komoly S. \& PALKovits M. (2015): Gyakorlati neurológia és neuroanatómia. Medicina Könyvkiadó, Budapest. 
LÁBADI B. \& BEKE A. M. (2016): A corpus callosum agenesia viselkedéses és kognitív profilja összefoglaló. Ideggyógyászati Szemle, 69(11-12): 373-379. doi:10.18071/isz.69.0373

MATÁNYI M. \& KÁKONYI M. (2018): Cervelox 2.0, avagy: Tudja-e a jobb szem, mit csinál a bal kéz? Hirbarát, 2018. június 12. (https://hirbarat.hu/2018/06/12/).

MÉSZÁROS L. GY. (2004): Taxonomical revision of the Upper Würm Sorex (Mammalia, Insectivora) remains of Hungary, for proving the presence of an alpine ecotype in the Pilisszántó Horizon. Annales Universitatis Scientiarum Budapestinensis de Rolando Eötvös Nominatae - Sectio Geologica, 34: 9-25.

MÉSZÁROS L. (2010): Ökoszisztéma változások kutatása a fosszilis bükki és recens alpi faunák összevetésével. In: KÁZMÉR M. (szerk.): Környezettörténet 2010 Konferencia - Környezeti események a honfoglalától napjainkig történeti és természettudományi források fényében. Az Általános Földtani Szemle Könyvtára, 3: pp. 61-62.

MÉSZÁROS L. (2011): Aktuopaleontológiai vizsgálatok a kelet-ausztriai Rax-hegységben. In: Kázmér M. (szerk.): Környezettörténet 2.: Környezeti események a honfoglalástól napjainkig történeti és természettudományi források tükrében. Hantken Kiadó, Budapest, 2011., pp. 253-263.

MÉSZÁROS L. (2014): Óriási törpék: Szörnyetegcickányok a Kárpát-medencében. Élet és Tudomány, 69 (3): 82-84.

Mészáros L. (2015a): Őslénytani kutatás és tehetséggondozás: Előzetes jelentés az alsó-pleisztocén Somssichhegy 2-es lelőhely Sorex-Crocidura fog-arány vizsgálatáról. Acta Pintériana, 1: 15-24.

MÉSZÁros L. (2015b): Pleisztocén paleoökológiai változások kutatása a Crocidura-Sorex (Mammalia, Soricidae) fog-arány meghatározás alapján. In: Emberi Erőforrás Támogatáskezelő (szerk.): Út a Tudományhoz 2015. Emberi Erőforrások Minisztériuma, Budapest, pp. 32-33.

Men, N., Falk, D., Sun, T., Chen, W., Li, J., Yin, D., Zang, L. \& Fan, M. (2014): The corpus callosum of Albert Einstein's brain: another clue to his high intelligence? Brain, 137: 1-8. doi:10.1093/brain/awt252

Motz, B. A., JAmES, K. H., \& Busey, T. A. (2012). The Lateralizer: a tool for students to explore the divided brain. Advances in physiology education, 36(3): 220-225. doi:10.1152/advan.00060.2012

Pazonyi P., Virág A., Gere K., Botfalvai G., Sebe K., Szentesi, Z. MÉszáros L., BotKa D., GASPARIK M. \& KORECZ L. (2018): Sedimentological, taphonomical and palaeoecological aspects of the late early Pleistocene vertebrate fauna from the Somssich Hill 2 site (South Hungary). Comptes Rendus Palevol, 17(4-5): 296-309. doi:10.1016/j.crpv.2017.06.007

SubAi P. \& FehÉr Z. (2002): Pintér László Ernő (1942. III. 6., Sopron - 2002. V. 18., Bécs). Folia Historico-Naturalia Musei Matraensis, 26: 7-14

SZENTÁGOTHAi J. \& RÉTHELYI M. (2006): Funkcionális Anatómia III. Medicina Könyvkiadó, Budapest. 